firmed by multiple blood and saline cultures. Coils have been re-used as many as 14 times without complications and without appreciable drop in dialysance of urea. These results corroborate previous reports (Johnson et al., 1969). It takes an experienced person about 15 minutes to prepare the coil for storage and an equal period of time to set it up for re-use.

\section{Comments}

Storage and re-use of coils can be done very effectively and easily. This method can be used in home dialysis and would considerably reduce the cost of chronic dialysis. In our experience the expenditure for new coils and tubing can be reduced to at least one-third simply by the re-use of coils. This technique is limited only by the occurrence of leaks, clotting within the coil, and sepsis. Contrary to previous reports, we have not found it necessary to use antibiotics or antiseptic solutions as prophylaxis against infection (Tchetchik et al., 1966; Johnson et al., 1969). Reinfusion of blood to the patient at the end of each dialysis has eliminated the problem of haemolysis in stored coil blood. We have rinsed the outside of the coil with cold tap-water to reduce bacterial growth and toxin formation on the outside of the membrane.

No haemorrhagic diatheses have been seen with re-use of coils in our experience, in contrast with a previous report (Tchetchik et al., 1966). With this technique the immediate postoperative period is not a contraindication to re-use of the coil (Tchetchik et al., 1966) because the stored coil contains only a small amount of heparin (500 to 1,000 units). Even regional heparinization can be performed with coils stored in the manner described.

\section{REFERENCES}

Johnson, C. E., et al. (1969). Fournal of the American Medical Association, 207, 2087.

Kolff, W. J., and Watschinger, B. (1956). Fournal of Laboratory and Clinical Medicine, 47, 969.

Shaldon, S., Silva, H., and Rosen, S. M. (1964). British Medical fournal, 2,411 .

Tchetchik, M., Nakamoto, S., and Kolff, W. J. (1966). Fournal of the American Medical Association, 196, 451.

\title{
Clinical Associations of II-Hydroxycorticosteroid Suppression and Non-suppression in Severe Depressive Illnesses
}

\author{
B. J. CARROLL,* M.B., B.SC., D.P.M. ; BRIAN DAVIES, † M.D., M.R.C.P., D.P.M., F.A.N.Z.C.P.
}

Cummary: Fifty patients with severe depression were separated into two groups by the responses of their plasma 11-hydroxycorticosteriod levels to a midnight dose of $2 \mathrm{mg}$. of dexamethasone. Clinical and questionary comparisons were made between the two groups of patients, who were similar as regards age, sex, and length of symptoms before admission to hospital. No differences were found between the groups of severely ill patients as regards the severity of their depression and anxiety assessed by questionary. Nevertheless, agitation was significantly greater in the patients whose corticosteroid levels were not suppressed by dexamethasone and adverse childhood experiences in those whose levels were suppressed.

\section{Introduction}

Carroll et al. (1968) showed that the plasma 11-hydroxycorticosteroid (11-OHCS) response to a midnight 2-mg. dose of dexamethasone phosphate was abnormal in 14 out of 27 severely depressed patients. Patients in the same ward with other psychiatric illnesses, and the same depressed patients on recovery, did not show this abnormality. Another test of hypothalamic function-the plasma 11-OHCS response to intravenous insulin-has also been shown to be abnormal in some severely depressed patients and was associated with dexamethasone unresponsiveness (Carroll, 1969). Butler and Besser

*Research Fellow, National Health and Medical Research Council, Department of Psychiatry, University of Melbourne.

†Cato Professor of Psychiatry, Department of Psychiatry, University of Melbourne, Clinical Sciences Building, Royal Melbourne Hospital, Melbourne, Victoria, Australia.
(1968) reported raised plasma and urinary corticosteroid levels, a disturbed diurnal rhythm, and adrenocortical resistance to dexamethasone suppression in three patients with severe depression. These abnormalities are similar to those observed in Cushing's syndrome but revert to normal with successful antidepressant treatment. A review of these and other studies in severe disorders of mood has led to the conclusions " that some severely depressed patients show an increase in adrenocortical activity and disturbances in the feedback control of A.C.T.H. release" and that "manic patients and some severely depressed patients show a normal pattern of adrenal-pituitary function" (Davies, 1969).

The present paper compares clinical and questionary data from two groups of patients admitted to hospital with a primary depressive illness, who have been separated by their plasma 11-OHCS response to dexamethasone, $10 \mu \mathrm{g} / 100 \mathrm{ml}$. being taken as the separation level.

\section{Subjects and Methods}

Fifty patients with severe depressive illnesses admitted consecutively as inpatients to the professorial psychiatric unit were studied. They were all typical melancholic patients with agitation, retardation, delusional and suicidal thoughts, as well as disturbance of sleep, appetite, and bowel function. The clinical data were obtained from patients and relatives and the presence or absence of certain clinical features of the history and mental state discussed and agreed on at a teaching session. In this regard "adverse childhood experiences" included death or prolonged absence of one or both parents before the age of 14, time spent in an orphanage or several foster homes, and gross parental discord. As regards previous personality features, attention was directed to pronounced obsessional 
features and definite mood variations. The Hamilton (1960) Depression Rating Scale was completed for all patients, and 23 of them were able to complete the Taylor (1953) Manifest Anxiety Scale.

All patients received the same general nursing and medical care and all were given a normal ward diet. The dexamethasone test was done five to seven days after admission to hospital, at which time no other drug but amylobarbitone was being given. Blood for plasma 11-OHCS estimations was collected in tubes containing 15 units of lithium heparin per $10 \mathrm{ml}$. of blood. Samples were collected at 8.30 a.m. Dexamethasone phosphate $2 \mathrm{mg}$. was given orally at midnight, and a further plasma 11OHCS sample taken at 8.30 a.m. the next day. Plasma 11OHCS determinations were measured by the fluorometric technique of Mattingly (1962) by means of a CGA spectrophotofluorometer (model DC/3000). The result of the dexamethasone test was not known at this time when treatment was planned on clinical grounds.

\section{Results and Discussion}

The results are shown in the Table. The depressed patients were separated on the plasma 11-OHCS response to dexamethasone, $10 \mu \mathrm{g} . / 100 \mathrm{ml}$. being taken as the separation level. It can be seen that after dexamethasone the mean 11OHCS level of the non-suppressors is $20.9 \mu \mathrm{g} . / 100 \mathrm{ml}$. compared with $4.7 \mu \mathrm{g} . / 100 \mathrm{ml}$. of the suppressors. Thus these depressed patients as a group could be significantly separated by the 11-OHCS response to dexamethasone. In addition, there was a significant difference in the initial plasma 11-OHCS levels. In each group the change of 11-OHCS level after dexamethasone was related to the initial level of plasma 11-OHCS (Suppressors $\mathrm{r}=-0.84, \mathrm{P}<0.01$; Non-suppressors $\mathrm{r}=-0.6$, $\mathrm{P}<0.01$ ).

The severity of the illness as judged by the Hamilton Depression Scale did not show a difference between the groups, but the subscore on agitation did, the non-suppressors having a significantly higher rating on agitation than the suppressors. The anxiety subscores on the Hamilton Depression Scale were the same in both groups of patients, as were the scores on the Taylor Manifest Anxiety Scale (completed by only 23 patients). No significant correlations were found between severity of illness as measured by the total Hamilton score and initial and post-dexamethasone 11-OHCS plasma levels.

This finding is contrary to our previous report (Carroll et al., 1968), when a clinical rating scale was used to measure severity of depression. A $\chi^{2}$ distribution above and below the median values in respect to the total scores on this scale showed a significant relationship with non-suppression. It will be noted, however, that in the present study 20 of the non-suppressors were treated with electric convulsion therapy (E.C.T.) compared with 14 of the suppressors, and 21 had lost more than $3.2 \mathrm{~kg}$. in weight compared with 15 of the suppressors.

A related study (Mcl_eod et al., 1969) of depressed patients attending for day hospital treatment has given similar information relevant to the question of severity of depression and 11OHCS responsiveness. The mean Hamilton Depression Score of this group of patients was 21.0 (S.D. 4.7) -that is, they were significantly less depressed $(P<0 \cdot 01)$ than the hospital inpatients of the present study. But when they were separated into 11-OHCS suppressors and non-suppressors by their response to dexamethasone, the mean Hamilton Depression Score of the two groups was the same, as in the present study.

No relation was found between plasma 11-OHCS levels and the presence or absence of suicidal thought content and suicidal attempts before admission to hospital. This is of interest as Bunney et al. (1969) found an association between 17-OHCS levels which were high in the urine and subsequent suicidal behaviour.

There were no differences in the two groups as regards age and sex distribution, nor in length of symptoms before admission to hospital. A past history of affective illness was found three times more often in the non-suppressors and their parents and siblings, but this difference was not statistically significant.

Significantly more of the suppressors had adverse childhood experiences $(\mathrm{P}<0 \cdot 05)$. Twice as many of the suppressors showed pronounced obsessional features in their personality but this difference was not statistically significant. There was no difference between the groups as regards obvious precipitating events before the onset of the illness.

Our previous paper (Carroll et al., 1968) showed that a group of patients with a primary depressive illness could be separated from a group of psychiatric patients without depressive symptoms by their plasma 11-OHCS response to dexamethasone. In addition, it was found that the initial plasma 11OHCS levels of the two groups were the same, and that on recovery from the depression the non-suppressors respond normally to dexamethasone.

The present clinical investigation has studied severely depressed patients admitted to hospital for treatment with a test of feedback control, and has compared "suppressors" and "non-suppressors." The level of agitation as recorded in this study was significantly different in the two groups of patients. Nevertheless, individual patients showing pronounced agitation suppressed plasma 11-OHCS normally, while other nonsuppressors did not show agitation. In general the presence or absence of steroid abnormality in the patients studied by the methods described could not be related to their clinical presentation. The causal relationship, if any, between nonsuppression and depressive illness remains to be determined.

Comparisons of Two Groups of Severely Depressed Patients Showing 11-OHCS Suppression $\left(<10_{\mu} \mathrm{g} / 100 \mathrm{ml}\right.$.) and Non-suppression by Dexamethasone

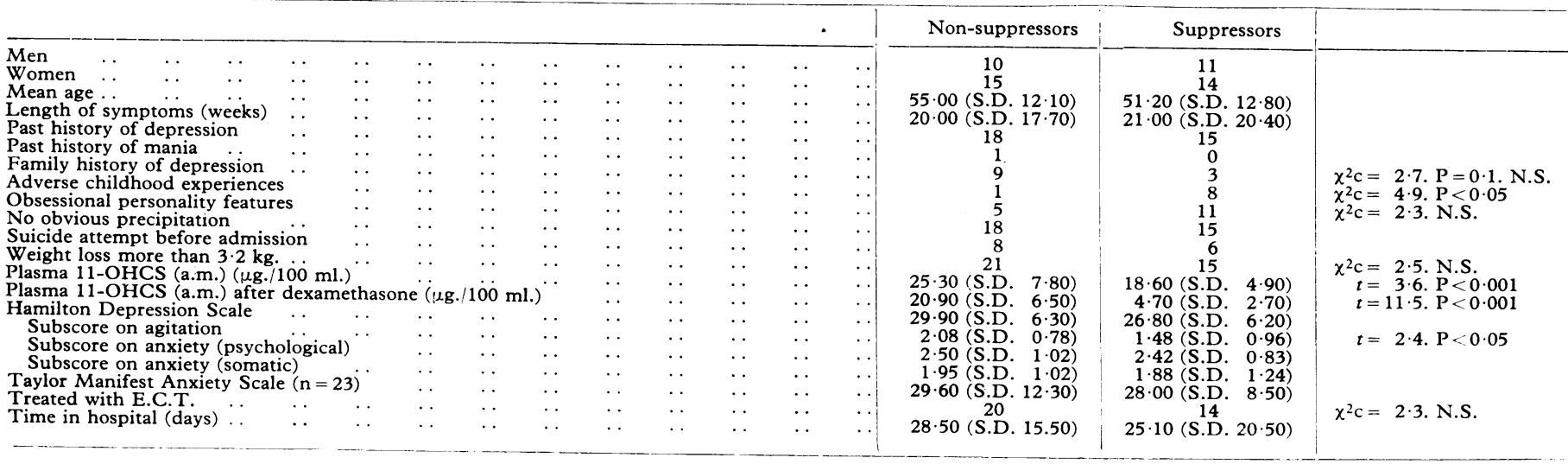


Further studies of larger numbers of patients should look at the trends that were found for those who suppressed normally to have more adverse childhood experiences and more obsessional personality features, and for the non-suppressors to have a greater number of past episodes of affective illnesses in themselves and their families. In addition, in our own clinical practice more of the non-suppressors are given E.C.T.

We are grateful to Dr. R. M. Mowbray, reader in medical psychology, for his advice on the statistical methods used.
REFERENCES

Bunney, W. E., Fawcett, J. A., Davis, J. M., and Gifford, S. (1969). Archives of General Psychiatry, 21, 138.

Butler, P. W. P and Besser, G. M (1968). Lancet, 1, 1234.

Carroll, B. J. (1969). British Medical fournal, 3, 27.

Carroll, B. J., Martin, F. I. R., and. Davies, B. (1968). British Medical fournal, 3, 285 .

Davies, B. M. (1969). Medical fournal of Australia, 1, 487, 557.

Hamilton, M. (1960). Fournal of Neurology, Neurosurgery and Psychiatry, 23, 56. McLeod, W. R., Carrol, B. J., and Davies, B. (1969). Unpublished
observations.

Mattingly, D. (1962). Fournal of Clinical Pathology, 15, 373.

Taylor, J. A. (1953). Fournal of Abnormal and Social Psychology, 48, 285.

\title{
Clinical Experience with Dextro-Alprenolol
}

\author{
J. K. VOHRA, ${ }^{*}$ M.D., M.R.C.P. ; P. L. THOMPSON, † M.R.A.C.P. ; J. G. SLOMAN, † F.R.C.P.ED., F.R.A.C.P.
}

British Medical fournal, 1970, 1, 791-792

Summary: Experience with dextro-alprenolol in nine $\checkmark$ patients has shown that it is relatively ineffective in treating arrhythmias associated with acute myocardial infarction. Marginal effectiveness in the control of ventricular ectopic beats after myocardial infarction is outweighed by an appreciable hypotensive effect with risk of infarction. The drug was ineffective in the management of supraventricular arrhythmias.

\section{Introduction}

Beta-adrenergic receptor blocking drugs have been used successfully in the control of supraventricular and ventricular arrhythmias after myocardial infarction, in digitalis intoxication, and during anaesthesia (Sloman and Stannard, 1967; Epstein and Braunwald, 1966; Vohra et al., 1970). This group of drugs, in addition to beta-adrenergic receptor blockade, have a direct effect on the myocardial cell membrane, termed "quinidinelike" activity (Sekiya and Vaughan Williams, 1964). This concept is supported by the demonstration that the two properties may reside in different stereo isomers of pronethalol, propranolol, and alprenolol (Johnsson et al., 1966).

The dextro isomer of alprenolol (Dextro H 56/28, D-alprenolol, D-Aptin, Astra Pharmaceuticals (Aust.) Pty. Ltd.) was reported to be as effective as the racemate in control of ouabaininduced ventricular arrhythmias (Duce et al., 1967; Lord et al., 1968) but has only minor beta-blocking activity. Linko et al., (1968) used dextro-alprenolol in 14 patients with a variety of acute arrhythmias and found that, in a dose of 5 to $20 \mathrm{mg}$. intravenously, it had no effect on the arrhythmias and no sideeffects were observed. In order to evaluate this drug we have used it to treat arrhythmias arising in patients while in the coronary care unit.

\section{Patients and Methods}

Details of nine patients aged 37 to 71 years admitted to the coronary care unit for treatment are given in Table I. Eight

\footnotetext{
* Ethnor Research Fellow

† Registrar.

The Royal Melbourne Hospital, Victoria 2050, Australia.
}

TABLE I.-Details of Cases

\begin{tabular}{|c|c|c|c|c|c|}
\hline $\begin{array}{l}\text { Case } \\
\text { No. }\end{array}$ & Age & Dose & Arrhythmia & \begin{tabular}{|c|} 
Systolic \\
Blood \\
Pressure \\
change (mm.)
\end{tabular} & $\begin{array}{l}\text { Effect on } \\
\text { Arrhythmia }\end{array}$ \\
\hline 1 & 71 & $\begin{array}{l}10 \mathrm{mg} . \mathrm{I} . \mathrm{V} . \\
\text { bolus }\end{array}$ & $\begin{array}{l}\text { Atrial flutter with } \\
\text { variable block, } \\
\text { ventricular rate } \\
105 / \text { min. }\end{array}$ & 140 to 118 & Nil \\
\hline 2 & 37 & $\begin{array}{l}10 \mathrm{mg} . \mathrm{I} . \mathrm{V} . \\
\text { bolus }\end{array}$ & $\begin{array}{l}\text { Atrial flutter with } \\
2: 1 \text { block }\end{array}$ & 85 to 75 & $\begin{array}{l}\text { Increased } \\
\text { carotid sinus } \\
\text { sensitivity }\end{array}$ \\
\hline 3 & 71 & $\begin{array}{l}20 \mathrm{mg} . \mathrm{I} . \mathrm{V} . \\
\text { bolus }\end{array}$ & $\begin{array}{l}\text { Supraventricular } \\
\text { tachycardia }\end{array}$ & 100 to 70 & Nil \\
\hline 4 & 38 & $\begin{array}{l}20 \mathrm{mg} . \mathrm{I} . \mathrm{V} . \\
\text { bolus }\end{array}$ & $\begin{array}{l}\text { Supraventricular } \\
\text { tachycardia }\end{array}$ & 80 to 70 & $\begin{array}{l}\text { No immediate } \\
\text { effect on } \\
\text { arrhythmia. } \\
\text { Collapsed after } \\
\text { propanidid.Slow } \\
\text { nodal rhythm }\end{array}$ \\
\hline 5 & 57 & $\begin{array}{l}25 \text { mg. I.V. } \\
\text { bolus }\end{array}$ & $\begin{array}{l}\text { Ventricular ectopics } \\
\text { bigeminy }\end{array}$ & 140 to 110 & $\begin{array}{l}\text { Nil. Arrhythmia } \\
\text { controlled with } \\
\text { lignocaine }\end{array}$ \\
\hline 6 & 42 & $\begin{array}{l}25 \text { mg. I.V. } \\
\text { bolus and } \\
200 \mathrm{mg} . \\
\text { infusion } \\
\text { over } 12 \\
\text { hours }\end{array}$ & $\begin{array}{l}\text { Ventricular ectopics } \\
\text { bigeminy }\end{array}$ & 140 to 100 & $\begin{array}{l}\text { Ventricular } \\
\text { ectopics } \\
\text { abolished. } \\
\text { S-T segment } \\
\text { raised with pain }\end{array}$ \\
\hline 7 & 50 & $\begin{array}{l}300 \text { mg. I.V. } \\
\text { infusion } \\
\text { over } 12 \\
\text { hours }\end{array}$ & $\begin{array}{c}\text { Ventricular ectopics } \\
\text { bigeminy }\end{array}$ & 100 to 70 & $\begin{array}{l}\text { Ectopics } \\
\text { abolished. } \\
\text { S-T segment } \\
\text { raised }\end{array}$ \\
\hline 8 & 47 & $\begin{array}{l}25 \text { mg. I.V. } \\
\text { bolus, then } \\
10 \mathrm{mg} . \mathrm{I} . \mathrm{V} . \\
\text { 2-hourly }\end{array}$ & $\begin{array}{l}\text { Ventricular } \\
\text { ectopics } 1 \text { in } 8 \\
\text { beats }\end{array}$ & $\begin{array}{l}125 \text { to } 100 \\
\text { immediately } \\
\text { after } 25 \mathrm{I} . \mathrm{V} . \\
\text { bolus }\end{array}$ & $\begin{array}{l}\text { Ventricular } \\
\text { ectopics } \\
\text { persisted }\end{array}$ \\
\hline 9 & 42 & $\begin{array}{l}300 \mathrm{mg} . \mathrm{I} . \mathrm{V} . \\
\text { infusion } \\
\text { over } 12 \\
\text { hours }\end{array}$ & $\begin{array}{l}\text { Slow ventricular } \\
\text { tachycardia }\end{array}$ & 105 to 70 & $\begin{array}{l}\text { Ventricular } \\
\text { tachycardia } \\
\text { persisted. } \\
\text { S-T segment } \\
\text { raised }\end{array}$ \\
\hline
\end{tabular}

were subsequently shown to have suffered an acute myocardial infarction in the 48 hours before admission and one had viral myocarditis. All these patients were admitted with or developed serious cardiac arrhythmias requiring treatment. Dextroalprenolol was used as the initial form of therapy and also as an infusion in a dose up to $0.45 \mathrm{mg}$./minute. The patients were monitored and carefully observed during its administration. In the event of an adverse effect, or when the arrhythmia failed to respond, the patient was treated with other drugs or direct current counter shock. 